\title{
Minimum alveolar concentration of isoflurane in dogs administered two morphine doses
}

\author{
Karina Coelho $^{1}$ Eduardo Raposo Monteiro ${ }^{1,2^{*}}$ Thais Feres Bressan ${ }^{1}$ \\ Betânia Souza Monteiro ${ }^{1}$ Daniela Campagnol ${ }^{1}$ Marcelo Meller Alievi $^{2}$
}

${ }^{1}$ Escola de Medicina Veterinária, Universidade Vila Velha (UVV), Vila Velha, ES, Brasil.

${ }^{2}$ Departamento de Medicina Animal, Faculdade de Veterinária, Universidade Federal do Rio Grande do Sul (UFRGS), 91540-000, Porto Alegre, RS, Brasil. E-mail: eduardo.monteiro@ufrgs.br. "Corresponding author.

\begin{abstract}
This study aimed to evaluate the effects of intramuscular $0.5 \mathrm{mg} \mathrm{kg}^{-1}\left(\mathrm{MOR}_{0.5}\right)$ and $1.0 \mathrm{mg} \mathrm{kg}^{-1}$ (MOR $\left.\mathrm{MO}_{1.0}\right)$ morphine premedication on the minimum alveolar concentration of isoflurane (ISO ${ }_{M a C}$ in dogs. Eighteen client-owned female dogs were scheduled for elective ovariohysterectomy. Dogs received intramuscular $M O R_{0.5}$ or MOR ${ }_{1.0}$ as premedication and propofol IV for induction of anesthesia. Isoflurane was delivered for maintenance of anesthesia and dogs were maintained under normocapnia and normothermia. Determinations of the ISO ${ }_{M A C}$ were conducted by use of the "up-and-down" method. Noxious stimulus (placement of Backhaus towel clamps, a midline skin incision and subcutaneous tissue dissection) was delivered approximately 50 minutes after premedication with MOR or. $_{\text {or }}$ MOR $_{1.0}$. The calculated ISO ${ }_{\text {MAC }}$ was $0.98 \pm 0.15 \%$ in $M_{0.5}$ and $0.80 \pm 0.08 \%$ in $M O R_{1.0}$. The $I_{S O} O_{M A C}$ was significantly lower in MOR ${ }_{I .0}$ compared with MOR ${ }_{0.5}(P=0.010)$.

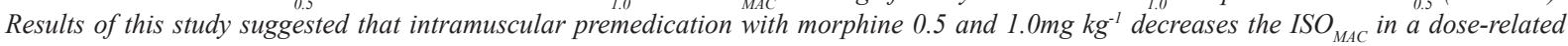
manner in dogs.
\end{abstract}

Key words: autonomic response, canine, inhalational anesthetics, opioids.

Concentração alveolar mínima do isoflurano em cães tratados com duas doses de morfina

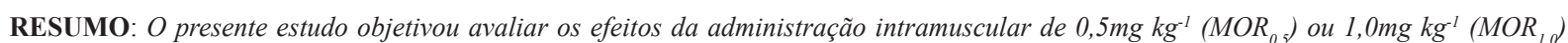
de morfina sobre a concentração alveolar mínima do isoflurano (CAM ISO em cães. Dezoito cadelas de proprietários foram agendadas para ovário-histerectomia eletiva. As cadelas receberam $M O R_{05}$ ou MOR ${ }_{l, 0}$, como medicação pré-anestésica, e propofol IV para indução da anestesia. A manutenção da anestesia foi realizada com isoflurano em condições de normocapnia a normotermia. A determinação da CAM ISo foi conduzida de acordo com o método "up-and-down". O estímulo nociceptivo (colocação de pinças Backhaus, incisão da pele na linha média e dissecção de tecido subcutâneo) foi realizado aproximadamente 50 minutos após a administração de $M O R_{0,5}$ ou $M_{O} O R_{1,0}$. A CAM ${ }_{I S O}$ calculada

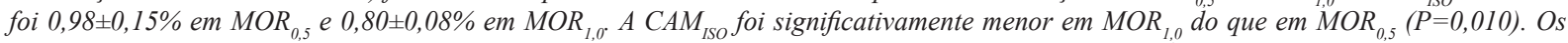
resultados do estudo sugerem que a medicação pré-anestésica com morfina nas doses de 0,5 e 1,0mg $\mathrm{kg}^{-1}$, pela via intramuscular, resulta em redução dose-dependente na $C A M_{\text {ISO }}$ em cães.

Palavras-chave: resposta autonômica, canino, anestésicos inalatórios, opioides.

Morphine has been used to provide analgesia/antinociception in dogs (MURPHY \& HUG, 1992; KO et al., 2009; AGUADO et al., 2011; MONTEIRO et al., 2016). As with other $\mu$-opioid agonists, morphine decreased the minimum alveolar concentration (MAC) of enflurane in a dose-related manner in dogs (MURPHY \& HUG, 1992). Morphine also decreased the MAC of isoflurane $\left(\mathrm{ISO}_{\mathrm{MAC}}\right)$ in dogs, but to the authors' knowledge, only studies evaluating a single dose of the opioid were conducted (STEFFEY et al.,
1994; KO et al., 2009). Moreover, in these previous studies, morphine was administered intravenously and only at high doses ( 1 to $\left.2 \mathrm{mg} \mathrm{kg}^{-1}\right)$. In clinical practice, morphine is usually administered as premedication, at doses ranging from 0.1 to $1.0 \mathrm{mg}$ $\mathrm{kg}^{-1}$, by intramuscular (IM) injection.

The present study evaluated the effects of IM $0.5 \mathrm{mg} \mathrm{kg}^{-1}\left(\mathrm{MOR}_{0.5}\right)$ and $1.0 \mathrm{mg} \mathrm{kg}^{-1}\left(\mathrm{MOR}_{1.0}\right)$ morphine premedication on the $\mathrm{ISO}_{\mathrm{MAC}}$ in dogs. The hypothesis was that morphine would decrease the $\mathrm{ISO}_{\mathrm{MAC}}$ in a dose-related manner. 
Eighteen healthy female dogs scheduled for elective ovariohysterectomy $(\mathrm{OH})$ were enrolled in the study. Any dog having clinical signs of systemic disease, abnormal laboratory data, or aged $<6$ months or $>8$ years was excluded from the study. The dogs were randomly administered IM $0.5 \mathrm{mg}$ $\mathrm{kg}^{-1}$ or $1.0 \mathrm{mg} \mathrm{kg}^{-1}$ morphine (Dimorf, Cristália) as premedication in the $\mathrm{MOR}_{0.5}$ group and $\mathrm{MOR}_{1.0}$ group, respectively.

Approximately 20 minutes after premedication, anesthesia was induced by administering propofol intravenously to allow endotracheal intubation. Dogs were positioned in dorsal recumbency on an electrical heating pad to maintain esophageal temperature between $37^{\circ} \mathrm{C}$ and $38^{\circ} \mathrm{C}$. Anesthesia was maintained with isoflurane (Isoforine, Cristália) in oxygen through a circle rebreathing system. Airway gases were sampled from between the endotracheal tube and the breathing system into an infrared gas analyzer (ILCA Sensor Module; Dräger) to monitor the end-tidal carbon dioxide $\left(\mathrm{ETCO}_{2}\right)$ and isoflurane (ETiso) concentrations. A standard calibration gas mixture (Agent/End-Tidal $\mathrm{CO}_{2}$ Calibration Gas, Smiths Medical) was used to verify the calibration of the gas analyzer. Dogs were mechanically ventilated to maintain the $\mathrm{ETCO}_{2}$ between 30 and $35 \mathrm{mmHg}$. Intraoperative monitoring included heart rate (HR), indirect (oscillometric) systolic (SAP), mean (MAP) and diastolic (DAP) arterial blood pressures, $\mathrm{ETCO}_{2}$ and esophageal temperature (Lifewindow 6000Vet, Digicare). The abovementioned variables were registered immediately before the noxious stimulus was delivered.

The noxious stimulus used for $\mathrm{ISO}_{\mathrm{MAC}}$ determination was delivered approximately 50 minutes after premedication with $\mathrm{MOR}_{0.5}$ or MOR $_{1.0}$. The ISO $_{\text {MAC }}$ was determined by the upand-down method as reported in previous studies in dogs (AGUADO et al., 2011; MONTEIRO et al., 2016). The ETiso for the first dog in each group was set at $0.8 \%$. On all occasions, an equilibration period of at least 15 minutes was allowed at the ETiso to be tested. Thereafter, the noxious stimulus was delivered: placement of four Backhaus towel clamps, a midline skin incision and subcutaneous tissue dissection. A single surgeon performed the noxious stimuli on all occasions. The response to noxious stimulus was classified as positive or negative if the dog did or did not move the head, trunk, or limbs within one minute after the stimulus. When a positive or negative response was observed, the ETiso to be tested in the subsequent dog from the same group was increased or decreased by $0.1 \%$, respectively. Observation of opposite responses in two consecutive dogs (positive followed by negative or vice-versa) was defined as a crossover. The ETiso concentrations tested in four independent crossovers were used to calculate the $\mathrm{ISO}_{\mathrm{MAC}}$ value in each group by mathematical averaging. After evaluation of the response to the noxious stimulus, all dogs were administered $0.6 \mathrm{mg} \mathrm{kg}^{-1} \mathrm{~S}(+)$-ketamine and $0.2 \mathrm{mg}$ $\mathrm{kg}^{-1}$ meloxicam intravenously and the ETiso was increased to maintain surgical depth of anesthesia to perform the $\mathrm{OH}$.

Data distribution was analyzed using the Shapiro-Wilk normality test. Differences between the groups in $\mathrm{ISO}_{\mathrm{MAC}}$, HR, SAP, MAP and DAP were compared by unpaired t test. A Mann Whitney test was used to compare propofol dose and age of dogs between groups. For all analyzes, a $\mathrm{P}$ value of $<0.05$ was considered significant.

Eighteen dogs completed the study (ten dogs in $\mathrm{MOR}_{0,5}$ and eight dogs in $\mathrm{MOR}_{1,0}$ ). There were no significant differences between the groups for age, weight and propofol induction dose; median (interquartile range) for all 18 dogs were 12 months (12-42 months), $11.4 \mathrm{~kg}(8.4-14.1 \mathrm{~kg})$ and $6.1 \mathrm{mg}$ $\mathrm{kg}^{-1}$ (5.1-7.0mg $\left.\mathrm{kg}^{-1}\right)$, respectively. There were no significant differences between the groups for temperature and $\mathrm{ETCO}_{2}$. Mean $\pm \mathrm{SD}$ temperature and $\mathrm{ETCO}_{2}$ for all 18 dogs were $37.1 \pm 0.3^{\circ} \mathrm{C}$ and $32 \pm 2 \mathrm{mmHg}$. Values for MAP and DAP were significantly lower in $\mathrm{MOR}_{1.0}$ than in $\mathrm{MOR}_{0.5}$ : $50 \pm 6 \mathrm{mmHg}$ versus $63 \pm 10 \mathrm{mmHg} \quad(\mathrm{P}=0.008)$; $31 \pm 7 \mathrm{mmHg}$ versus $40 \pm 7 \mathrm{mmHg} \quad(\mathrm{P}=0.020)$, respectively. There was a trend for lower values of $\mathrm{HR}$ and SAP in $\mathrm{MOR}_{1.0}$ than in $\mathrm{MOR}_{0.5}: 59 \pm 10$ beats min ${ }^{1}$ versus $74 \pm 18$ beats $\min ^{-1}(\mathrm{P}=0.056) ; 79 \pm 8 \mathrm{mmHg}$ versus $93 \pm 16 \mathrm{mmHg}(\mathrm{P}=0.051)$, respectively. The mean $\pm \mathrm{SD}$ calculated $\mathrm{ISO}_{\mathrm{MAC}}$ was $0.98 \pm 0.15 \%$ in $\mathrm{MOR}_{0.5}$ and $0.80 \pm 0.08 \%$ in $\mathrm{MOR}_{1.0}$ (Figure 1). The $\mathrm{ISO}_{\mathrm{MAC}}$ was $18 \%$ lower in $\mathrm{MOR}_{1.0}$ compared with $\mathrm{MOR}_{0.5}(\mathrm{P}=0.010)$.

In a previous study, the $\mathrm{ISO}_{\mathrm{MAC}}$ determined in dogs was $1.20 \%$ (MONTEIRO et al., 2016). This previous study was performed in the same laboratory and using the same methodology of the present study. Because a control $\mathrm{ISO}_{\mathrm{MAC}}$ had already been determined in this previous study (MONTEIRO et al., 2016), we decided not to include a control group in the present study. In the study reported here, the estimated $\mathrm{ISO}_{\mathrm{MAC}}$ in the $\mathrm{MOR}_{0.5}$ and $\mathrm{MOR}_{1.0}$ groups is respectively $18 \%$ and $33 \%$ lower than the $1.20 \%$ value reported in the 

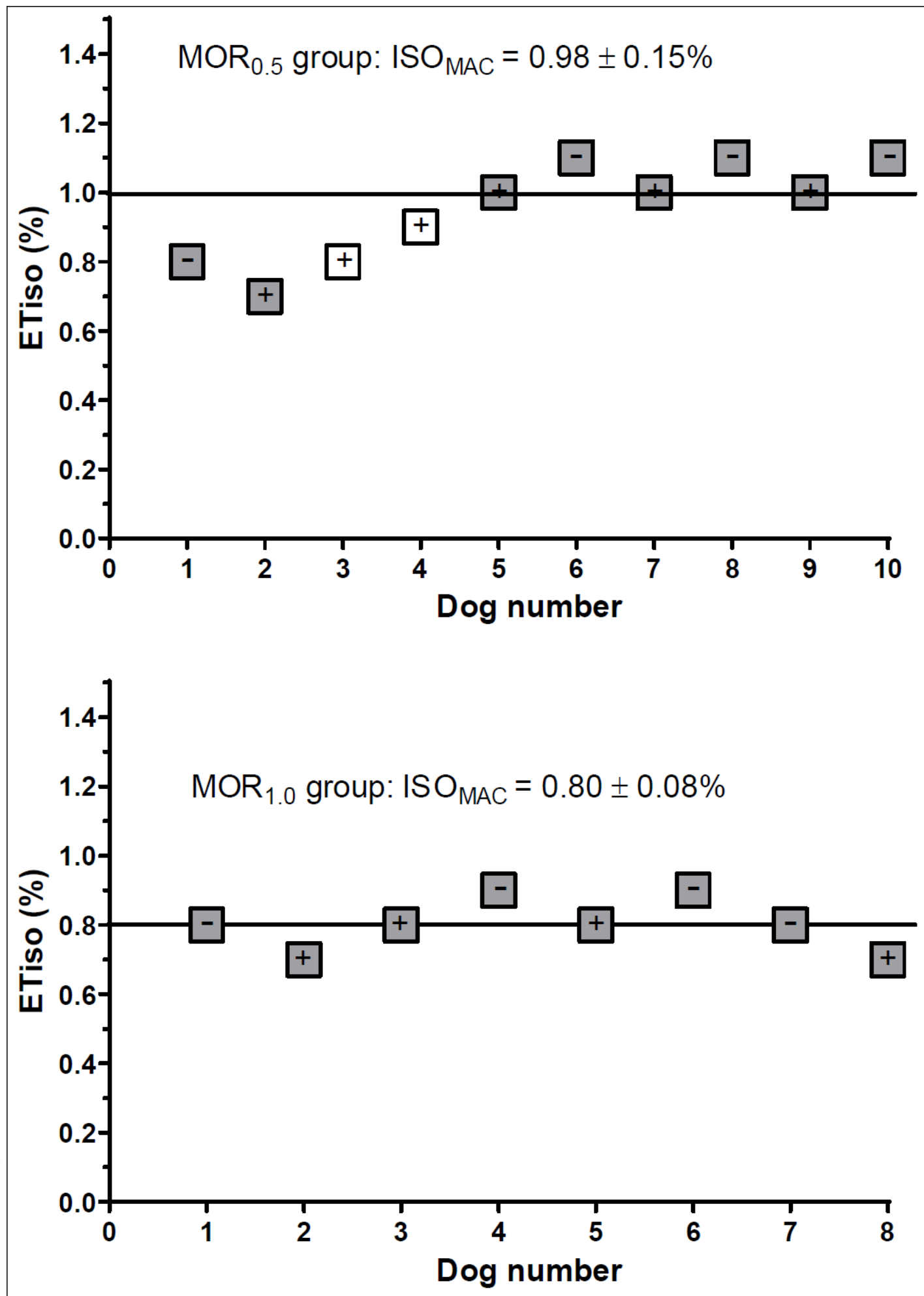

Figure 1 - Response (positive or negative) for each of the 18 anesthetized dogs at the respective end-tidal isoflurane concentration tested (ETiso). Before anesthetic induction with propofol, the dogs were administered $0.5 \mathrm{mg}$ $\mathrm{kg}^{-1}$ morphine $\left(\mathrm{MOR}_{0.5}\right.$ group, $\left.n=10\right)$ or $1.0 \mathrm{mg} \mathrm{kg}^{-1}$ morphine $\left(\mathrm{MOR}_{1.0}\right.$ group, $\left.n=8\right)$. ( + ) indicates a positive response; (-) indicates a negative response; shaded squares indicate the crossovers. The horizontal lines indicate the calculated mean $\mathrm{ISO}_{\mathrm{MAC}}$ value. 
control group by MONTEIRO et al. (2016). The findings of the present study are in agreement with a previous study that demonstrated a dose dependent reduction on enflurane MAC by morphine in dogs (MURPHY \& HUG JR, 1982).

In the present study, the noxious stimulus used for determination of the $\mathrm{ISO}_{\mathrm{MAC}}$ may not be considered a supramaximal stimulus (VALVERDE et al., 2003). Nevertheless, the reduction in the $\mathrm{ISO}_{\mathrm{MAC}}$ reported in a previous study (KO et al., 2009), which employed a supramaximal noxious stimulus for MAC determination in dogs administered $1.0 \mathrm{mg} \mathrm{kg}^{-1}$ morphine IV, was nearly the same compared to the $\mathrm{MOR}_{1.0}$ group (34\% versus $33 \%$ ). These findings indicated that the upand-down method employing dogs from clinical practice can be a good alternative for determination of the MAC sparing effect of sedative or analgesic drugs. However, other studies need to be performed to support this statement.

Pure $\mu$-opioid agonists induce vagal stimulation on medullary centers and decrease in HR (LAUBIE et al., 1979). This effect was reported to be dose related such that progressively increasing doses of alfentanil decreased HR in a dose dependent manner in dogs (ARNDT et al., 1986). The finding that HR was lower in the $\mathrm{MOR}_{1.0}$ group than in the $\mathrm{MOR}_{0.5}$ group suggests that the higher dose of morphine induced a more pronounced vagal stimulation than the lower dose of the opioid in this study.

Based on mean values for each group, hypotension (MAP $<60 \mathrm{mmHg}$ ) was observed in $\mathrm{MOR}_{1.0}$ but not in $\mathrm{MOR}_{0.5}$. This was an unexpected finding as isoflurane is known to induce dose related cardiovascular depression in dogs (PAGEL et al., 1991). Therefore, a higher MAP would be expected in $\mathrm{MOR}_{1.0}$ than in $\mathrm{MOR}_{0.5}$ because the $\mathrm{ISO}_{\text {MAC }}$ was $18 \%$ lower in this group. The event of mild hypotension (MAP $=50 \pm 6 \mathrm{mmHg}$ ) in $\mathrm{MOR}_{1.0}$ might be considered a limitation of this study because hypotension decreased halothane MAC in dogs (TADIKONDA et al., 1981). In this previous study, the decrease in MAC was observed after a reduction in MAP from approximately $100 \mathrm{mmHg}$ to $60 \mathrm{mmHg}$ and the MAC was not evaluated in intermediate levels of MAP (TADIKONDA et al., 1981). In addition, the results from this previous study using halothane can not be extrapolated to isoflurane anesthesia. Further studies are necessary to evaluate the influence of different levels of MAP on the $\mathrm{ISO}_{\mathrm{MAC}}$. In conclusion, results of this study suggest that IM premedication with morphine 0.5 and $1.0 \mathrm{mg} \mathrm{kg}^{-1}$ decreases the $\mathrm{ISO}_{\mathrm{MAC}}$ in a dose-related manner in dogs.

\section{BIOETHICS \\ AND COMMITTEE APPROVAL}

BIOSSECURITY

This study was approved by the Institutional Animal Care Committee (protocol 195/2011) and all owners gave their informed consent.

\section{ACKNOWLEDGEMENTS}

We thank Coordenação de Aperfeiçoamento de Pessoal de Nível Superior (CAPES) for providing a scholarship to Karina Coelho and Thais Bressan. Funding for this research was provided by Conselho Nacional de Desenvolvimento Científico e Tecnológico (CNPq).

\section{REFERENCES}

AGUADO, D. et al. Reduction of the minimum alveolar concentration of isoflurane in dogs using a constant rate of infusion of lidocaine-ketamine in combination with either morphine or fentanyl. Veterinary Journal, v.189, p.63-66, 2011. Available from: $<$ http://www.ncbi.nlm.nih.gov/pubmed/20594878>. Accessed: Nov. 30, 2015. doi: 10.1016/j.tvj1.2010.05.029.

ARNDT, J.O. et al. Alfentanil's analgesic, respiratory, and cardiovascular actions in relation to dose and plasma concentration in unanesthetized dogs. Anesthesiology, v.64, p.345-352, 1986.

KO, J.C. et al. Effects of carprofen and morphine on the minimum alveolar concentration of isoflurane in dogs. Journal of the American Animal Hospital Association, v.45, p.19-23, 2009. Available from: $<$ http://www.jaaha.org/doi/abs/10.5326/0450019?code=amah-site $>$. Accessed: Feb. 20, 2017. doi: 10.5326/0450019.

LAUBIE, M. et al. Vagal bradycardia produced by microinjections of morphine-like drugs into the nucleus ambiguus in anaesthetized dogs. European Journal Pharmacology, v.59, p.287-291, 1979. Available from: <https:/www.ncbi.nlm.nih.gov/pubmed/?term=527649>. Accessed: Aug. 09, 2017. doi: 10.1016/0014-2999(79)90292-9.

MONTEIRO, E.R. et al. Effects of acepromazine-morphine and acepromazine-methadone premedication on the minimum alveolar concentration of isoflurane in dogs. Veterinary Anaesthesia and Analgesia, v.43, p.27-34, 2016. Available from: <http://www.ncbi. nlm.nih.gov/pubmed/25880906>. Accessed: Feb. 20, 2017. doi: $10.1111 /$ vaa. 12265 .

MURPHY, M.R.; HUG, C.C. The enflurane sparing effect of morphine, butorphanol, and nalbuphine. Anesthesiology, v.57, p.489-492, 1982.

PAGEL, P.S. et al. Comparison of the systemic and coronary hemodynamic actions of desflurane, isoflurane, halothane, and enflurane in the chronically instrumented dog. Anesthesiology, v.74, p.539-551, 1991.

STEFFEY, E.P. et al. Morphine-isoflurane interaction in dogs, swine and rhesus monkeys. Journal of Veterinary Pharmacology and Therapeutics, v.17, p.202-210, 1994. Available from: $<$ https:// www.ncbi.nlm.nih.gov/pubmed/?term=7933058>. Accessed: Aug. 09, 2017. doi: 10.1111/j.1365-2885.1994.tb00234.x.

TADIKONDA, L.K. et al. Deliberate hypotension and anesthetic requirements of halothane. Anesthesia and Analgesia. v.60, p.513-516, 1981. 